\title{
Collaboration between Indonesia and WFP in East Nusa Tenggara on the Issue of Food Security
}

\author{
Dessiana Nurul Fitri; Mansur Juned; Andi Kurniawan \\ Department of International Relation, Universitas Pembangunan Nasional 'Veteran' Jakarta, Indonesia \\ http://dx.doi.org/10.18415/ijmmu.v9i2.3489
}

\begin{abstract}
This research aims to describe the Collaboration between Indonesia and WFP in the field of food security and achieving SDGs No. 2, Zero Hunger, based on the problem of food security in Indonesia. Seeing some of the problems faced by Indonesia such as the difficulty in meeting food needs, the high rate of population growth, climate change, the ability of food production and Indonesia's dependence on imported products, are the core of this collaboration. WFP wants to help Indonesia to establish food by implementing its programs in Indonesia. One of the objects of program implementation carried out by WFP in Indonesia is the province of NTT as an example of a province that is vulnerable and food insecure. This research uses qualitative research methods and is supported by the theory of international Collaboration, Sustainable Development and Food Security.
\end{abstract}

Keywords: International Collaboration; Indonesia; World Food Program; Sustainable Development Goals; Zero Hunger; Food Security

\section{Introduction}

In the global world order, the concept of food security has expanded from just meeting food availability to having to pay attention to nutrition and consumption feasibility to realize a healthy and active life (Nashir, 2015). But on the other hand, the problem of food security is still engulfing the world as a strategic issue. The issue of food security in the world is related to the three aspects of food security that have not been achieved, such as food availability, access to food, and food utilization which are interrelated with each other.

The Province of East Nusa Tenggara (NTT) is one of the provinces in Indonesia that has multiple burdens of food security problems. The multi-burden problems that occur in NTT Province ${ }^{1}$ are food insecurity, stunting, malnutrition, and also anemia in pregnant women. In the 2015, 81 sub-districts have vulnerable conditions (Priorities 1-3), which describes 27 percent of the 300 sub-districts in NTT Province, the prevalence of stunting under five in NTT Province in 2015 was $41.2 \%$. The prevalence of wasting toddlers in NTT Province in 2015 was also 13.6\%, the prevalence of underweight toddlers in

\footnotetext{
${ }^{1}$ Provinsi Nusa Tenggara Timur
} 
2015 was $25.6 \%$ which makes NTT Province the highest position for malnutrition and under-five nutrition problems. (World Food Programme, 2015).

In addition, there are global demands to achieve the zero hunger sustainable development goal which demands that Indonesia must also solve its food security problem to achieve zero hunger by 2030. So Indonesia needs assistance from the World Food Program as the world's largest food organization under the auspices of the United Nations to provide policy advice to support the Government of Indonesia in its efforts to achieve the Sustainable Development Goals and to achieve the target of reducing the number of people who are highly food insecure by 9 million by 2020 .

This research will focus on the Collaboration between Indonesia and $\mathrm{WFP}^{2}$ in overcoming the problem of food security in East Nusa Tenggara Province through the periodization of the Indonesia Country Program 2016-2020. The Indonesia Country Program will also discuss the achievement of Sustainable Development Goals in NTT Province, especially Point 2, namely Zero Hunger or Zero hunger which is in line with the Indonesia Country Program 2016-2020.

\section{Methods}

To achieve a firm understanding of the collaboration between Indonesia and the World Food Program in solving food security issues in the NTT Province, this research uses a qualitative method, namely a case study. The type of research is descriptive-qualitative and the sources are obtained through semi-closed interviews and also library studies. The data obtained were analyzed using the theory of international Collaboration, food security, and sustainable development goals. The theory of Collaboration is used to discuss the technical Collaboration between Indonesia and WFP, the concept of food security is used to discuss aspects that must be achieved to achieve food security such as food availability, food utilization, and food availability, then sustainable development goals are used to be the indicator to achieve the aim of Collaboration between Indonesia and WFP.

\section{Result and Discussion}

\section{Food Security Condition of NTT Province}

Food security includes three aspects, such as availability, affordability, and utilization. The availability aspect relates to the food supply to meet the needs of the entire population, both in terms of quantity, quality, and diversity. The aspect of affordability relates to the ability of the community to be able to obtain food. While the utilization aspect is related to the use of food by households and the ability of individuals to absorb and metabolize nutrients, including storage, processing and preparation of food, water safety for drinking and cooking, hygiene conditions, feeding habits, distribution of food in the household in accordance with individual needs, and the health status of each household member.

\section{A. Food Availability}

Aspects of food availability (normative consumption per capita to net availability ratio). The average daily calorie consumption per capita is $2,031.60 \mathrm{kcal}$ and the largest source of calories comes from grains $(1,217.45 \mathrm{kcal})$ and tubers $(60.24 \mathrm{kcal})$ (World Food Programme, 2015). This figure shows that the daily consumption of rice is quite high or in other words, a large portion of processed rice is served on the food plates of the NTT people, while the local food crops of the NTT Province actually do not have sufficient production availability to fulfill it. And the average protein consumption per capita per day is 55.92 grams, which is actually the largest source of grains (28.90 grams) (World Food Programme, 2015). As an archipelagic province, the average per capita protein consumption of fish is only 6.72 grams per day, while consumption of other protein sources such as meat, eggs, and milk is still low.

\footnotetext{
${ }^{2}$ World Food Program 


\section{B. Access to food}

Household access to food has a high correlation with poverty status or economic access. In NTT Province, the regional poverty rate decreased from 23.31 in 2009 to 19.06 percent in 2014 but increased again in March 2015 to 22.61 percent. Currently, there are still 1.16 million people living below the poverty line. Compared to other provinces in Indonesia, NTT is still in the ranking of the 3rd highest poverty after Papua and West Papua (World Food Programme, 2015).

Then for social access, the NTT Open Unemployment Rate in August 2015 reached 3.83\%, the total working-age population 15 years and over (15+) was 3.33 million and those who worked were 69.25 percent (BPS Provinsi NTT, 2020).

Physical access or access to connecting facilities is also very important to determine the level of connectivity between villages which determines food accessibility and distribution as well as food prices. There are still 14 sub-districts ( 4.7 percent) of which 40 percent or more of the villages do not have access to roads or adequate transportation (World Food Programme, 2015).

\section{Food Utilization}

At the provincial level, 44.20 percent of households did not have access to clean and safe drinking water in 2013 while only 30.50 percent had access to proper sanitation facilities (World Food Programme, 2015).

At the provincial level, 85.25 percent of villages have access to health facilities less than $5 \mathrm{~km}$ away. However, there are eight out of 300 sub-districts ( 2.67 percent), of which more than 40 percent of villages do not have health facilities less than $5 \mathrm{~km}$ apart (World Food Programme, 2015).

The literacy rate of women, which is related to the practice of feeding patterns and the impact on child nutrition, increased significantly, with the number of illiterate women decreasing from 14.66 percent in 2009 to 11.31 percent in 2013 (World Food Programme, 2015).

\section{Government Efforts Before Collaborating with the World Food Program}

The Food Security Council explains strategic plans aimed at increasing food security in NTT Province through various programs/activities concerning food supply, including:

a. Stabilization of food availability through increased production of agriculture, animal husbandry, fisheries, and forestry;

b. Development of community food barns and provision of food reserves;

c. Handling food-insecure areas through short-term/emergency interventions (food assistance), medium-term (assistance to increase production), and long-term (through community empowerment, namely the Nusa Makmur Operation Program (ONM), Nusa Hijau Operation Program (ONH), Program to Improve People's Original Income (Gempar), Village Development Program (Gerbades));

d. Development of agribusiness institutions, including the Community Food Distribution Institution (LDPM), Farmers' Cooperatives, etc.;

e. Increasing the application of agricultural, animal husbandry, fishery, and forestry technology;

f. Improvement and empowerment of extension workers; 
g. Construction and improvement of irrigation networks, water resources, and other irrigation networks;

and h. Coordination of planning, implementation, control, and evaluation of food security development (Provinsi Nusa Tenggara Timur, 2018).

Meanwhile, the NTT Province Government itself has formed two programs to improve community welfare by handling, stunting, sanitation, and repair of livable houses, and improving the economy of a decent community, the NTT Prosperous Program and the NTT Bangkit Program (Provinsi Nusa Tenggara Timur, 2018).

Indonesia-United Nation World Food Program Collaboration in Overcoming Food Security Problems in East Nusa Tenggara Through Indonesia Country Program 2016-2020

In 2016, this collaboration was approved on February 10, 2016, and has been running since March 1, 2016, and will be completed on December 10, 2020. The Collaboration Program between Indonesia and WFP in the NTT Province in the field of food security is the Provincial Food Vulnerability and Security Atlas (FSVA), School Meals Program (PROGAS), Maternal and Child Health Program (KIA), Cash and Voucher/Sembako Program, and also the preparation of RAD-PG and RAD-SDGs.

\section{Provincial Food Vulnerability and Security Atlas (FSVA)}

FSVA is used to map districts or sub-districts that experience food vulnerability and insecurity. The result of this collaboration is a reduction in food insecurity and vulnerability because this map of vulnerability and food security can help focus areas with a priority scale of $1-3$, as evidenced by the decline in food insecurity and vulnerable areas in 2015 namely 81 sub-districts from a total of 300 subdistricts to 61 sub-districts out of a total of 303 sub-districts (Bodamaev, 2021).

\section{School Meals Program (PROGAS)}

School meals program (PROGAS) includes three types of activities: i) Nutrition education; ii) life skills training; and iii) provision of school meals. The targets of Progas are selected districts and schools to provide adequate nutrition for children. This program is an effort to help food security issues such as food availability, access to food, and food utilization (Supraptinah, 2021).

Nutrition education includes the involvement of PKK mothers, parents, and local teachers to cook and introduce menus and food recipes that are nutritious and also have economic value. The economic value here relates to the mothers and parents who are involved and also get paid work in the cooking process and help socialize nutritious food recipes. In addition, PROGAS also has a good impact that is also felt by local farmer groups because the food ingredients obtained are prioritized from local food plants (Supraptinah, 2021). This nutrition education is a form of effort in improving the problem of access to food, such as providing training so that mothers in NTT Province can work to make nutritious food and at the same time use food, namely the food produced is beneficial in terms of improving the nutrition and health of school children in the province. NTT (Supraptinah, 2021).

In addition to nutrition education, life skills training is also carried out by covering healthy and clean living habits, making school gardens that can be useful and have economic value if developed. These two activities are comprehensively useful for school children from elementary to junior high school and also the local economy (Supraptinah, 2021).

For the provision of school meals, the provision is done through a healthy breakfast that meets 400-500 kcal of energy and 10-12 grams of protein per day. The provision of school meals to improve food availability in terms of the number of calories for daily consumption by the community. 


\section{Maternal and Child Health Program (KIA)}

The Maternal and Child Health Program includes the BIAS (School Child Immunization Month) Program and also the PMT (Supplementary Food Provision). The targets of these two programs are school children for the BIAS program and the PMT program for school children and pregnant women. School children who are targeted to receive the BIAS program are expected to avoid measles and the PMT program to avoid stunting and malnutrition, while the PMT program for pregnant women is carried out so that pregnant women avoid anemia and malnutrition during pregnancy. The implementation time of the BIAS Program is once a month and the PMT Program is carried out every day (Supraptinah, 2021). The expected results from this program are the proportion of children aged 6-23 months consuming an adequate and varied minimum diet, acceptance and compliance with consuming complementary foods and biscuits, improving knowledge, attitudes and behavior regarding infant and young child feeding.

\section{Cash and Voucher / SEMBAKO Program}

The Cash and Voucher Program is a collaboration between WFP and the Social Service/Ministry of Social Affairs. This program is a modification of the Ranstra (Beras Sejahtera) program in 2016 and in 2017 this program began to implement a non-cash distribution modality using the banking system. The form of cash and voucher assistance distributed is known in Indonesian as Non-Cash Food Assistance (BPNT) which can be used as a medium of exchange for buying and selling at e-warung. For BPNT, the funds received per family head are around Rp. 150,000 per month. The target of this program is families who are included in the Family Hope Program (PKH). With the implementation of the BPNT Program, the Ranstra Program is still being implemented for areas that do not have adequate telecommunications and signal networks. In 2017, the Kupang City Government had 15 e-warung units to facilitate transactions for residents of PKH recipients (Kementerian Sosial, 2020).

In 2020, BPNT has renamed Cash and Voucher Program to SEMBAKO Program and also experienced an improvement in the value of assistance to Rp. 150,000 per family head every month. This SEMBAKO program is obtained through electronic coupons and can be used to buy various food products. However, during the COVID-19 pandemic, the SEMBAKO Program was temporarily packaged into Rp. 200,000-Rp. 300,000 / family to help cope with the impact of the pandemic (Kementerian Sosial, 2020).

\section{The Preparation of RAD-PG and RAD-SDGs.}

The RAD-PG (Regional Action Plan for Food and Nutrition) is a derivative of the RAN-PG (National Action Plan for Food and Nutrition) which is useful as the basis for planning food and nutrition development in the regions in line with the Regional Medium-Term Development Plan (RPJMD). In the 2016-2020 NTT Province RAD-PG, the programs implemented focused on improving community nutrition. This RAD-PG also supports the Scaling Up Nutrition (SUN) Movement which emphasizes the importance of multi-sectoral Collaboration in handling nutritional problems (Boli, Baliwati, \& Sukandar, 2018). Meanwhile, the RAD-SDGs is a derivative of the National Action Plan - Sustainable Goals Development. WFP assists the preparation as an actor who provides knowledge transfer and technical guidance to achieve food security and also sustainable development goals, especially sustainable development goals No. 1 without poverty and No. 2 without hunger.

The Result of Collaboration between Indonesia (NTT Province) and WFP

\begin{tabular}{|c|c|c|c|c|}
\hline Year & $\begin{array}{c}\text { Availability } \\
\text { Index }\end{array}$ & $\begin{array}{c}\text { Affordability } \\
\text { Index }\end{array}$ & $\begin{array}{c}\text { Utilization } \\
\text { Index }\end{array}$ & $\begin{array}{c}\text { Food Security } \\
\text { Index }\end{array}$ \\
\hline 2019 & 91,35 & 26,96 & 38,00 & 50,69 \\
\hline 2020 & 85,26 & 57.36 & 60,71 & 66,92 \\
\hline \multicolumn{2}{r|}{ Figure $1:$ NTT Province Food Security Index (Availablity, Affordability, and Utilization) }
\end{tabular}


The result of the collaboration between the Province of NTT and the World Food Program which includes five Collaboration programs is with a low food security index score, in 2019 the food security status of East Nusa Tenggara Province is a vulnerable province and food insecure with the third last position out of 34 provinces in Indonesia. with a food security index value of 50.69. However, in 2020, the food security of the NTT Province is getting better with an Food Security Index value of 66.92, then NTT Province is no longer included in the province with a Low Food Security Index (Janti, 2021).

As for Collaboration in realizing sustainable development goal number 2, zero hunger. There are several achievements related to this collaboration, such as: The prevalence of undernourishment in NTT Province is 14.19 and this situation is not too bad compared to the provinces of West Kalimantan, West Papua, Maluku, North Maluku, and Papua (World Food Programme, 2020). For the score of the NTT Province Daily Food Pattern, with a nutritional adequacy rate of 2,000/kcal/cap/day in 2015 with a score of 71.1. The score has an increase of 71.2 in 2018 while for PPH with a nutritional adequacy rate of 2,150 $\mathrm{kcal} / \mathrm{cap} /$ day in 2015 of 67.9 also increased by 68.0 in 2018 (World Food Programme, 2020), Prevalence of Stunting (Short and Very Short) in Children Under 5 Years/Toddlers in NTT Province are broken down from 2016-2018 as follows: 2016 was 23.72, 2017 was 22.3 and 2018 was 26.7 for toddlers who were categorized as short, while for very short toddlers in 2016 it was 15, 03, in 2017 it was 18 and in 2018 it was 16 (Badan Pusat Statistik, n.d.). Meanwhile, data from the Ministry of Home Affairs shows a decline in the stunting rate in the East Nusa Tenggara Region from $35.4 \%$ in 2018, to $30.3 \%$ in 2019 , and this consistently continues to decline in 2020 to $28.2 \%$ (Kemendagri, 2020)

This collaboration between the Province of NTT and the World Food Program has reduced several food security problems in the Province of NTT, such as the problem of food availability, access to food, and food utilization. The collaboration between NTT Province and WFP has made a significant contribution through VAM and EPR Activities for Strategic Outcome 1 - SDG Target 2.1. The achievement of sustainable development goal number 2, namely without hunger, cannot be separated from increasing food security, nutrition, and nutrition as well as sustainable agriculture through the establishment of NTT Province FSVA so that the government can concentrate on areas that are vulnerable and food insecure and at a higher level. Strategic Outcome 2 - Target SDG 2.2 through nutrition, social protection, and school meals programs such as the Maternal and Child Health Program through the Provision of Supplementary Food, the School Child Nutrition Program, and the Cash and Voucher Program. From some of these advances, it is still necessary to have a continuous commitment to the NTT provincial government and local communities to continue the programs that have been initiated by the WFP and the Central Government previously so that the collaboration does not cause interdependence and can achieve food self-sufficiency in the NTT Province.

\section{Conclusion}

Food insecurity is felt to be very complex, such as hunger, malnutrition, stunting, anemia in pregnant women, poverty, lack of access to good water and sanitation, as well as access to health services and facilities. For this reason, a collaboration framework was formed to improve and enhance food security in Indonesia. This collaboration which aims to improve food security in Indonesia is also in line with the number 2 global sustainable development goal, Zero Hunger. This collaboration is carried out by Indonesia and the United Nations World Food Program.

The central government, regional governments, and international organizations have attempted to respond to food insecurity in NTT Province with various programs. However, the efforts made have not been fully able to overcome the problem of food insecurity and nutrition and to achieve Zero hunger. Vulnerability and vulnerability in the province of NTT have decreased, but it has not been able to have achieved the goal of sustainable development without hunger. 


\section{References}

Badan Pusat Statistik. (n.d.). Persentase Balita Pendek Dan Sangat Pendek (Persen). Retrieved from https://www.bps.go.id/indikator/indikator/view_data/0000/data/1325/sdgs_2/1

Bodamaev, S. (2021, Juli 29). Kondisi Ketahanan Pangan Indonesia dan NTT Tahun 2016-2020. (D. N. Fitri, Interviewer)

Boli, E. B., Baliwati, Y. F., \& Sukandar, D. (2018). Komitmen Politik dan Peluang Pengembangan Kebijakan Gizi Pemerintah Daerah Provinsi Nusa Tenggara Timur. Jurnal MKMI, Vol.14 No.4, Desember 2018, 356.

BPS Provinsi NTT. (2020). Indeks Pembangunan Manusia (IPM) NTT Tahun 2020. Nusa Tenggara Timur. Retrieved from https://ntt.bps.go.id/pressrelease/2021/01/04/1011/indeks-pembangunanmanusia--ipm--ntt-telah-mencapai-65-19.html

Janti, H. (2021, April 28). Kondisi Ketahanan Pangan Indonesia, Provinsi NTT dan Kerjasama BKP dengan WFP. (D. N. Fitri, Interviewer)

Kemendagri. (2020). Trend Prosentase Balita Stunting di NTT 2018-2020 Konsisten Menurun. Retrieved from https://aksi.bangda.kemendagri.go.id/v2/in/main/news_detail/227/124/1779

Kementerian Sosial. (2020). Pedoman Umum Program SEMBAKO 2020. Retrieved from https://kemensos.go.id/uploads/topics/15828061583725.pdf

Nashir, A. K. (2015). Politik Kebijakan Pangan Nasional dalam Era Otonomi dan Globalisasi. Jurnal Kajian Lemhannas Edisi 22, 25-37.

Provinsi Nusa Tenggara Timur. (2018). Rencana Pembangunan Jangka Menengah Daerah 2018-2023. Kupang: Provinsi Nusa Tenggara Timur.

Supraptinah, N. (2021, Agustus 5). Kerjasama Pemerintah Indonesia dan WFP Kupang. (D. N. Fitri, Interviewer)

World Food Programme. (2015). Peta Kerentanan dan Ketahanan Pangan Provinsi NTT Tahun 2015. Kupang: World Food Programme.

World Food Programme. (2020). Peta Kerentanan dan Ketahanan Pangan Provinsi NTT Tahun 2020. Kupang: World Food Programme.

\section{Copyrights}

Copyright for this article is retained by the author(s), with first publication rights granted to the journal.

This is an open-access article distributed under the terms and conditions of the Creative Commons Attribution license (http://creativecommons.org/licenses/by/4.0/). 